\title{
DE DUPLOS E ESTEREOSCÓPIOS: PARALELISMO E PERSONIFICAÇÃO NOS CANTOS XAMANÍSTICOS AMERÍNDIOS*
}

Pedro de Niemeyer Cesarino

Este é um estudo sobre exemplares de artes verbais ameríndias relacionados a dinâmicas xamanísticas provenientes principalmente da América do Sul. De cantos e narrativas serão aqui enfocadas suas estruturações paralelísticas, não exatamente via uma análise dos traços formais, estilísticos ou retóricos, mas sim de suas implicações conceituais para a compreensão dos papéis da reiteração, da justaposição e da repetição, envolvidas em relações personificantes. Revisando algo do que tem sido dito sobre o paralelismo em tradições orais, o presente artigo dialoga também com certas considerações recentes da etnologia americanista (como a noção de pessoa e de predação), e encaminha uma via possível de estudo do paralelismo nas estéticas transformacionais xamanísticas.

\section{Ver e ouvir dizer}

Considerado por autores diversos, como Finnegan (1992), Zumthor (1983) e Lord (1985), como recurso essencial à mnemotécnica, ao estilo e ao modo de composição em performance oral, o paralelismo encontra em certos estudos de Jakobson (1970; 1985) algumas de suas reflexões mais fundamentais. Revendo a vasta bibliografia dedicada à antiga poesia chinesa, ao folclore russo e altaico, bem como ao parallelismus membrorum dos textos bíblicos, o lingüista ultrapassava diversos dos pressupostos e preconceitos outrora atribuídos às repetições verbais. Suas investigações sobre paralelismus membrorum - isto é, sobre o desdobramento de um só pensamento em dois membros paralelos do mesmo verso ou estrofe - levavam-no à idéia de que a reiteração não apenas extrapola o limite dos versos isolados, como também o das próprias palavras. Assim dizia, citando Herder: 
Herder atacou resolutamente a idéia, bastante repetida, de que "o paralelismo é monótono e representa uma contínua tautologia" [...] A sucinta resposta de Herder - "Nunca viu uma dança?" - seguida de uma comparação da poesia hebraica com uma dança, transferiu o paralelismo gramatical da classe da debilidade congênita e de seus remédios à categoria apropriada do procedimento poético intencional (Jakobson 1985:287).

Por seus jogos de variação, recombinação e justaposição de temas, fórmulas e padrões, o paralelismo não deixa de se mostrar presente em áreas tão diversas como a dança, a música, o cinema e mesmo na própria dinâmica transformacional dos mitos, como tanto se observa nas Mitológicas de LéviStrauss. Considerando o paralelismo a partir dos princípios de semelhança e contigüidade, Jakobson, vale lembrar, unificava a compreensão dos níveis sintáticos e semânticos da reiteração em sua noção de paralelismo gramatical (Fox 1977:70). Não mais visto como uma expressão das "redundantes mentes primitivas" encarceradas na repetição, mas sim como essência mesma do artifício poético, o paralelismo engendra a "figura de gramática" de que falava Gerard Manley Hopkins. Ultrapassando a idéia do verso isolado, Jakobson o inseria no "ambiente verbal próximo e distante" e em sua "rede de múltiplas afinidades vinculantes" (Jakobson 1985:294): a repetição paralelística, já dizia Sapir, mobiliza duas sentenças justapostas que nada mais são do que uma e a mesma, "diferindo apenas pelo revestimento material" (citado por Jakobson 1970:69). A visão binocular criada pela sobreposição de duas imagens, assim como a própria sensação estereoscópica fornecida por tal justaposição, conduzia Jakobson a aproximações com a montagem cinematográfica. Bem a propósito, dizia o autor:

a justaposição de conceitos gramaticais contrastantes pode ser comparada ao chamado 'corte dinâmico', um tipo de corte em que, na definição de Spottiswoode, por exemplo, a justaposição de tomadas ou seqüências contrastantes é utilizada para suscitar idéias na mente do espectador, idéias estas que não são veiculadas por cada tomada ou seqüência em si (Jakobson 1970:74).

Artes verbais ameríndias - em especial as relacionadas ao xamanismo - em muito utilizam tal princípio: cada linha nada mais é do que fragmento de uma imagem maior em que vemos a pessoa do cantador se deslocar por posições outras do cosmos. Analisando um canto dos Nenets siberianos, coletado em meados do século XIX, Simoncsics (1978) observou aí estarem o paralelismo e a forma musical a serviço "dos propósitos da visualização, e não da narração", pois "embora o encantamento seja sobre uma viagem, a viagem do xamã, ele não narra a viagem, mas antes a visualiza" via a estru- 
tura paralelística que o compõe (Simoncsics 1978:402). Muito embora não pensemos ser tal apelo visual um critério suficiente para a aproximação dos cantos xamanísticos ${ }^{1}$ a alguma espécie de lírica, como sugeria Simoncsics (1978:402), os paralelismos e as montagens parecem de fato prestar-se à visualização dos eventos paralelos que a pessoa cindida do xamã/cantador experiencia. Partido entre o que constantemente traduzimos por seu aspecto corporal e seu(s) outro(s) aspecto(s), almas, duplos ou princípios vitais, o locutor de cantos xamanísticos freqüentemente relata, reporta e torna visíveis seus trajetos, visitas, diálogos e sobreposições a miríades de subjetividades ou pontos de vista (Viveiros de Castro 2002b).

Se aqui comentamos o paralelismo, não o fazemos para encontrar mais um caso particular de fenômenos gerais da oralidade: a inquietação de Jullien a respeito do paralelismo na China é, de certa forma, também a nossa para o caso ameríndio. "Ao ler Tu Fu", escreve Jullien (1989:8), "o sinólogo nutre o sentimento de que o emparelhamento aí funciona de modo distinto do que alhures", a despeito da "vocação generalista que os lingüistas exercem com mais comodidade do que outros". Mas será isso, segue o autor, uma "queda, pela estreiteza da especialização, nas ilusões de uma 'especificidade'?"(Jullien 1989:8). Se na China (mas também nas Américas) o paralelismo é um procedimento textual (Jullien 1989:9), nem por isso ao texto se reduz" . Na China "existe um elo essencial entre, por um lado, a lógica do emparelhamento e, por outro [...], os efeitos do paralelismo que caracterizam a sua expressão" (Jullien 1989b:50). É justamente "o jogo do paralelismo no seio do texto que permite articular a dualidade", por exemplo, da relação entre yin e yang, característica de fenômenos como a adivinhação, a poesia escrita, a filosofia e as especulações cosmológicas.

Definir tecnicamente o paralelismo - por exemplo, do modo proposto por Finnegan (1992:98), como “uma espécie de repetição (em geral em um padrão binário) na qual um elemento é trocado e o outro (em geral a própria estrutura sintática) permanece constante" - não deve, portanto, nos fazer desviar de nossa questão: nos discursos xamanísticos, o paralelismo está a serviço de que configuração (cosmoprática) dos fenômenos de repetição e justaposição? Ao se utilizar disso que concebemos como um recurso lingüístico (o paralelismo), de que podem estar falando as poéticas xamanísticas? A seguinte constatação de Walton sobre os Navajo é significativa: "de fato, a composição dos cantos Navajo é muito similar aos seus velhos cobertores, nos quais a linha colorida de uma de suas extremidades equilibra a linha do outro extremo, em geral da mesma cor" (citado por Finnegan 1992:100).

Diversas são as formas de paralelismo observáveis nas versões escritas de cantos e narrativas com que trabalharemos aqui: o paralelismo interno 
aos próprios constituintes de um verso ou uma sentença (chamado de "microparalelismo"); a "oposição de dois termos colocados no seio de uma estrutura repetida identicamente" (Becquelin-Monod 1986:8), como no caso dos dísticos Maya; a repetição exaustiva de versos idênticos (como no caso Palikur [Miranda 2005:165] ou Ojibwa [Severi 2004:179]) na qual, quando muito, uma palavra apenas varia em algum instante da composição; a ligação entre linhas ou versos por meio de um elo (chain paralellism, nos termos de Finnegan [1992]) ${ }^{3}$, entre diversas outras variações de linhas dentro de estrofes (quando as há), de estrofes entre si e destas estrofes e linhas dentro de blocos que, também articulados em relações de variação e repetição, constituem o que chamamos de "macroparalelismo".

É comum que a posição de tais blocos, versos e estrofes seja recombinada pelo cantador em performance, tendo em vista não apenas a rápida composição imediata do canto via um procedimento mnemotécnico, como a demarcação de um regime especial de enunciação (a separação entre o discurso ordinário e ritual $l^{4}$ ) e, veremos aqui, também o uso propriamente agentivo das repetições e das variações, como no caso dos cantos de cura. A diversidade dos paralelismos (bem como sua tradutibilidade entre diversos domínios semióticos) pode assim ser compreendida como fruto de uma "alternância entre variação e constância", como recentemente definiu Severi (2004:146) ao aliar o estudo de cantos xamanísticos às tradições pictográficas ameríndias, compreendidas pelo autor como uma mnemotécnica figurada (Severi 2004:184) - reveladora, diga-se de passagem, do caráter visual do paralelismo, cujo sentido para a agência ritual xamanística estamos perseguindo.

O canto sámbadabts siberiano de que falávamos antes encaminhará nosso ponto. Tal canto, dizíamos, não é uma narrativa mítica: a descrição das viagens do xamã (tadyebya) não nos fala de um passado remoto rememorado pela narração. Tratando das ações realizadas "alhures" pelo xamã, na tentativa de solucionar "aqui" um parto difícil, o canto justapõe diálogos e imagens de suas visitas, via uma estruturação paralelística repleta de inversões e simetrias que "não se presta apenas a conectar duas linhas ou sintagmas, desempenhando também um papel decisivo na construção da composição lingüística como um todo" (Simoncsics 1978:388-390). Não apenas de tal composição, diríamos, mas também da cena por ela veiculada. É o que nos mostra o seguinte fragmento, em que vemos o cantador dialogar com entes outros, bem como estancar certo rio de sangue:

(...)
(12) tâweda xôninawa?
(12) Então encontramos
(13) ńârcon xôjm xôninawa?
(13) O cume musgoso, encontramos, 
(14) ńârcon xôjn t’ajana

(15) lôrca úeda tańewî,

(16) lôrcam úedam pôrjuwî?

(17) úîw tânso pôrjuwî?

(18) "tânso ńewe xâdakaw,

(19) ôbom ńúda târinín

(20) ńâsadan târińin!"

(21) tânso nuü nâasanaw

(22) xenkixina pôrjuwî.

(23) sçram xôjm xôninawa?

(24) sçran xôjn xäewxana

(25) xem jaxa tanew $\hat{\imath}$,

(26) xew jaxa xajeparya

(27) jçntalida xajeparna

(28) xew jaxa jçntakana

(29) matoraje xôriăana

(30) äeptarida tirconâ??

(31) xew jaxam jçnâwem?

(32) pç ńâni jçnâwem?

(33) xew jaxa matedâ

(34) jçntalida mat'edâ,

(35) xew jaxam madâwa?
(14) no pé do cume musgoso

(15) um monte gramado,

(16) o monte gramado atravessado por

(17) atravessado por sete lagartos

(18) "Mãe lagarto, avó,

(19) dê uma criança

(20) dê à minha amiga!"

(21) A criança lagarto, minha amiga,

(22) surgindo ao meu lado.

(23) Encontramos o cume de gelo,

(24) ao lado do cume de gelo

(25) havia um rio de sangue,

(26) o rio de sangue corria,

(27) a correnteza corria,

(28) na correnteza do rio de sangue

(29) a ser cortado

(30) tranças de cabelo flutuam.

(31) Eu corto o rio de sangue

(32) apenas com as mãos eu o corto,

(33) o rio de sangue parou

(34) a correnteza parou,

(35) cruzamos o rio de sangue.

$(\text { Simoncsics 1978:388-389) })^{5}$

Vemos aí como a oscilação dos pronomes pessoais ('nós' oculto nos versos 12 e 13, 'eu' nos versos 31 e 32) indica estar o cantador em companhia de gentes outras, em um trajeto visualizado pelo encadeamento das imagens. Tal economia discursiva e imagética de artes verbais xamanísticas, vale frisar, não é a do ouvir dizer narrativo, mas a da evidência direta das ações excorporadas do cantador (Taylor 1993; Viveiros de Castro 1986; Cesarino 2003): se, nas narrativas, a visualização encontra-se subsumida pela autoridade mediatizada de algum narrador, nos cantos parece ocorrer o contrário. É antes a própria visualização que transmite a evidência e constitui a fonte primeira de carga epistêmica da palavra que se quer verdadeira, não por remeter sua competência a uma fonte ancestral, mas por ser justamente o próprio locutor a autoridade e a fonte imediata do que comunica, bem como o depositário das expectativas de eficácia de seus feitos ${ }^{6}$.

Tomemos o exemplo das akinhá ekugu, as "histórias verdadeiras" dos Kuikuro do alto Xingu (Franchetto 2002a). A dinâmica das enunciações, das 
reiterações e das montagens de blocos aí encontrada parece ser de outra natureza que a envolvida no uso do paralelismo em cantos ligados a práticas xamanísticas. Os Kuikuro utilizam o termo otohongo - o mesmo-outro, ou o outro-mesmo (Franchetto 2002a:30) - para definir a duplicidade produtora da derivação, da sinonímia e da repetição paralelística de suas narrativas (Franchetto 2002a:3). Além de encontrada na própria estrutura gramatical da língua, tal repetição evidencia também a lógica dos duplos títulos das akinhá: a de que extraímos um curto fragmento recebe, por exemplo, o nome aruak Jamugikumalu ("hiper-fêmeas") e karib itão kwegü etinkipügü ("transformadas em hiper-fêmeas"). Por meio de complexas combinações da estrutura macro (entre grandes blocos ou cenas da narração) e microparalelística (interna aos blocos), a akinhá narra as relações diferenciais entre os seres ekugu e os seres "hiper", os itseke (Franchetto 2002a:15). A articulação dos blocos promove, nota Franchetto, "um crescendo dramático" (Franchetto 2002a:15) que enfatiza a transformação dos homens - distantes que estão da aldeia em virtude de uma expedição de caça - em seres itseke, "hiper queixadas" no caso. Os blocos macroparalelísticos da metamorfose masculina são colocados em oposição aos blocos macroparalelísticos da metamorfose das mulheres, que aguardam na aldeia pelo retorno dos homens. Ao descobrirem que seus maridos estão se transformando alhures em itseke, as mulheres transformam-se elas próprias em hiper-fêmeas. No mito, o jovem Kamatahigagi assim se dirigia à sua mãe, relatando a transformação dos homens por ele testemunhada:

Mãe, creia em mim, são seres como estes que esperamos, são os pais ... ama, ige-hungu makina ku-m-bangami-tagï-ko-i apaju-ko-i e todavia eles queriam me alimentar

ige-hunu u-enge-ho-tagï solaka i-heke-ni

eles queriam me alimentar

u-enge-ho-tagï leha i-heke-ni leha

os pais

apajuko heke

é verdade, lá, creia em mim, os pais estão prestes a se transformar, agora

ilá sotïmak-ige-i apaju-ko i-tsagï ige-i

eram os dentes deles que saíam

is-i-gü-ko ihati-ga-tïhïgï

seus pêlos sobre eles

ipu-gu-ko leha i-sae-ni leha

sobre os dorsos enfim seus pêlos...

i-tsupo-ni leha ipugu-ko leha ... (Franchetto 2002a:14)7 
A disposição paralelística, observa Franchetto, não é aí gratuita e muito menos redundante: antes oferece "saliência cognitiva" ao conteúdo de rito e mito, bem como ao antagonismo cosmológico entre os gêneros, que é evidenciado na narrativa pela relação meta-paralelística entre os blocos de metamorfoses (Franchetto 2002a:20). Em cantos voltados para a agência xamanística, porém, tal "saliência cognitiva" desencadeada por montagens de eventos está a serviço de outros fins que aqueles envolvidos na economia discursiva das narrativas. Os cantos relacionados à agência ritual veiculam não a rememoração e a mediação que constituem o evento narrativo, mas a ação imediata e atual da pessoa múltipla do cantador/especialista. Casos diversos existem, evidentemente, em que narrativas e cantos xamanísticos se entrecruzam $^{8}$; mais ainda, as ditas narrações "míticas" não apenas desenvolvem situações propriamente "xamanísticas" (como no caso das transformações acima descritas pela akinhá), como o fazem de modo performativo (donde a compreensão do narrar como um evento, de acordo com o que diremos mais abaixo). Ainda assim, as performances xamanísticas mobilizam a reiteração e o prolongamento de imagens (semelhantes às que encontramos, por exemplo, nas akinhá Kuikuro) de modo a salientar o caráter imediato, a agência e a necessidade de eficácia em face das situações visualizadas, nas quais o ponto de vista do locutor está em relação direta com os participantes dos eventos (isto é, as pessoas/interlocutoras outras [mortos, divindades ou espíritos], freqüentemente entrelaçadas complexas metafóricas e embutimentos enunciativos). Os cantos huni muka dos Kaxinawá (Guimarães 2002:212-ss.) em muito ilustram tais especificidades do paralelismo mobilizado por artes verbais ligadas a práticas xamanísticas. Referentes aos usos e aos rituais do nixi pae (ou ayahuasca [Banisteriopsis caapi]), os huni muka são propriamente caminhos. Os dami, suas imagens, representações ou transformações visionárias são os caminhos (bai) abertos pelo nixi pae capazes de colocarem o cantador em relação aos yuxin ("espíritos") ali presentes, ou ao "povo do nixi pae", aqueles que realmente compreendem as palavras especiais do canto composto na língua dos antigos (shenipabu hãtxa). O huni muka sobrepõe/comunica o huni, a pessoa que canta, a Yube, a sucuri ancestral hipóstase do cipó, bem como o próprio cipó-homem (pois a ayahuasca é uma pessoa para os Kaxinawá e tantos outros povos amazônicos).

Longos e reiterativos, tais cantos possuem um tom recitativo e uma curva melódica pouco acentuada; perto de seu fim, tendem a "adquirir um ritmo vertiginoso de elocução, reforçado pelo staccato das sílabas regulares e pelo caráter reiterativo dos versos" (Guimarães 2002:211). Acompanhados de estribilhos, os huni muka são dotados de uma cadência encantatória, cujo ritmo "serve como um dinamizador das imagens que vão sendo impulsionadas paratática e paralelisticamente, em uma montagem que oscila, dialeticamente, entre a quebra e a continuidade" (Guimarães 2002:214-215). Seus estribilhos dizem muito também da sinestesia, outra característica notável de certas imagéticas xamanísticas ${ }^{9}$ : 
Cada som [do estribilho] tem uma luz diferente, uma luz ou então daquelas forças. Tem várias luzes, cores: azul, vermelho, brilhoso. E tem vários nomes de cipó diferente: baka, pati, shawa, shane [...] o pati é verde, bem macio; o baka é bem leve e brilhoso, branco como escama de peixe; shawa é daqueles vermelhos, tipo sangue - quando pega mesmo, você vê sangue igual chuva; tem shane que é azul, um pássaro bem azul. Cada cipó tem sua cor e suas músicas (Norberto Sales Tene citado por Guimarães 2002:211-212).

Na música do huni muka, o cantador joga com um conjunto razoavelmente fixo de versos, combinando "indefinidamente e com grande liberdade seqüências inteiras do canto, alternando versos e repetindo-os ao sabor da sua - ou de alheia - inspiração" (Guimarães 2002:214). Um esquema de tal combinação é apresentado abaixo, acompanhando o original em shenipabu hãtxa (a língua dos antigos), a fim de esclarecer ao leitor algo do jogo das reiterações e das estruturas paralelísticas dos versos, estrofes e cenas em questão (Guimarães 2002:216-217) ${ }^{10}$.

(1) Dua meke newene, haia e e, ha e eee

(2) Pae txakabaya, haia e e, ha e eee

(3) Yura kibi tanakin, haia e e, ha e eee

(4) Huni karu mururi, haia e e, ha e eee

(5) Miki niri itani, haia e e, ha e eee

(6) Huni karu peseri, haia e e, ha e eee

(7) Tapex ana beime, haia e e, ha e eee

(8) Tapex ana beime, haia e e, ha e eee

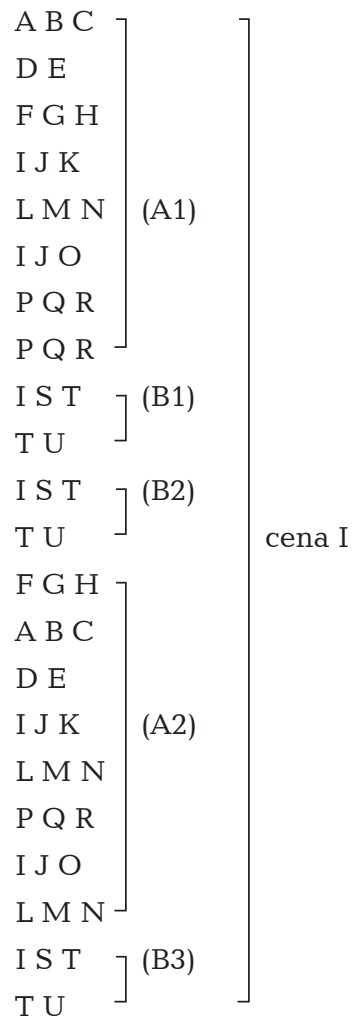

(9) Huni shãku shaiayume, haia e e, ha e eee

(10) Shaia yume kaitã, haia e e, ha e eee

(11) Huni shãku shaiayume, haia e e, ha e eee

(12) Shaia yume kaitã, haia e e, ha e eee

(13) Yura kibi tanakin, haia e e, ha e eee

(14) Dua meke newene, haia e e, ha e eee

(15) Pae txakabaia, haia e e, ha e eee

(16) Huni karu mururi, haia e e, ha e eee

(17) Miki niri itani, haia e e, ha e eee

(18) Tapex ana beime, haia e e, ha e eee

(19) Huni karu peseri, haia e e, ha e eee

(20) Miki niri itani, haia e e, ha e eee 
(23) Hawe dau tibuya, haia e e, ha e eee

(24) Yube bãu dãuti, haia e e, ha e eee

(25) Yube bãu dãuti, haia e e, ha e eee

(26) Yube hushu puketi, haia e e, ha e eee

(27) Yube hushu besuya, haia e e, ha e eee

(28) Yube hushu besuya, haia e e, ha e eee

(29) Yube hushu puketi, haia e e, ha e eee

(30) Hawe niti namaki, haia e e, ha e eee

(31) Niti bai namaki, haia e e, ha e eee

(32) Hawe niti namaki, haia e e, ha e eee

(33) Bari shubi birimi, haia e e, ha e eee

(34) Uraramu buani, haia e e, ha e eee

(35) Txere hushu keyua, haia e e, ha e eee

(36) Hawe niti namaki, haia e e, ha e eee

(37) Bari shubi birimi, haia e e, ha e eee

(38) Txere hushu keyua, haia e e, ha e eee

(39) Uraramu buani, haia e e, ha e eee

(40) Bari tau birimi, haia e e, ha eee

(41) Yawa hushu keyua, haia e e, ha e eee

(42) Tãu tãu yuanã, haia e e, ha e eee

(43) Bari tau birimi, haia e e, ha e eee

(44) Yawa hushu keyua, haia e e, ha e eee

(45) Tãu tãu yuanã, haia e e, ha e eee

(46) Txibu teshka dakatã, haia e e, ha e eee

(47) Ninka duku iniwe, haia e e, ha e eee

(48) Txibu teshka dakatã, haia e e, ha e eee

(49) Ninka duku iniwe, haia e e, ha e eee

(50) Shawe hana kaitã, haia e e, ha e eee

(51) Ninka duku iniwe, haia e e, ha e eee

(52) Hawe niti namaki, haia e e, ha e eee

(53) Yube bãu dãuti, haia e e, ha e eee

(54) Yube hushu puketi, haia e e, ha e eee

(55) Yube hushu besuya, haia e e, ha e eee

(56) Hawe niti namaki, haia e e, ha e eee

(57) Yube bãu dãuti, haia e e, ha e eee

(58) Yube hushu puketi, haia e e, ha e eee

(59) Yube hushu besuya, haia e e, ha e eee

(60) Ninka duku iniwe, haia e e, ha e eee

(61) Txibu teshka dakatã, haia e e, ha e eee

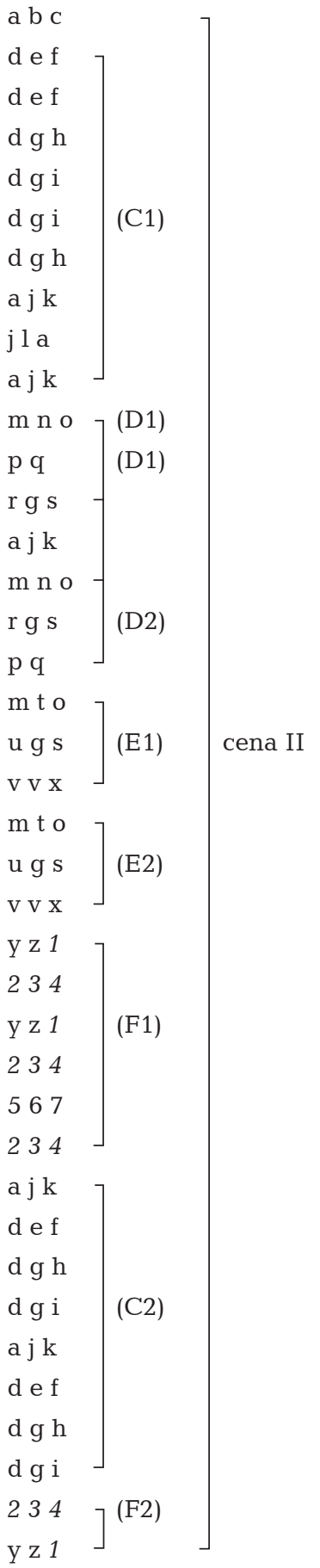


(1) Na mão imensa da onça

(2) A força moendo moendo

(3) O corpo inteiro seguindo

(4) O homem - lenho estalando

(5) Sobre ti, agora, caindo

(6) O homem - lenho rachando

(7) Faísca quente chegando

(8) Faísca quente chegando

(9) O homem - gomo esticado

(10) Esticado o talo nascendo

(11) O homem - gomo esticado

(12) Esticado o talo nascendo

(13) O corpo inteiro seguindo

(14) Na mão imensa da onça

(15) A força moendo moendo

(16) O homem - lenho estalando

(17) Sobre ti, agora, caindo

(18) Faísca quente chegando

(19) O homem - lenho rachando

(20) Sobre ti, agora, caindo

(21) O homem - gomo esticado

(22) Esticado o talo nascendo

(23) Com o encanto guardado

(24) Jibóia - baú de encantos

(25) Jibóia - baú de encantos

(26) Jibóia branca fez de ponte

(27) Jibóia branca cara a cara

(28) Jibóia branca cara a cara

(29) Jibóia branca fez de ponte

(30) Com ela parada no meio

(31) Parada dentro da passagem
(32) Com ela parada no meio

(33) Gameleira cheia de frutas

(34) Zoando levou embora

(35) Nuvem de curica branca

(36) Com ela parada no meio

(37) Gameleira cheia de frutas

(38) Nuvem de curica branca

(39) Zoando levou embora

(40) Paxiúba cheia de frutas

(41) Nuvem de queixada branca

(42) Tan-tan queixo batendo

(43) Paxiúba cheia de frutas

(44) Nuvem de queixada branca

(45) Tantan queixo batendo

(46) O cacho apoiado no esteio

(47) Ouvindo primeiro subindo

(48) O cacho apoiado no esteio

(49) Ouvindo primeiro subindo

(50) Jabuti esticando a língua

(51) Ouvindo primeiro subindo

(52) Com ela parada no meio

(53) Jibóia - baú de encantos

(54) Jibóia branca fez de ponte

(55) Jibóia branca cara a cara

(56) Com ela parada no meio

(57) Jibóia - baú de encantos

(58) Jibóia branca fez de ponte

(59) Jibóia branca cara a cara

(60) Ouvindo primeiro subindo

(61) O cacho apoiado no esteio

O canto justapõe e recombina as unidades verbais até criar o efeito da cena total trazida pelo nixi pae. A sobreposição da pessoa do cantador à do cipó-gente, bem como o encontro subseqüente com Yube e os yuxin ("espíritos", "almas", "pessoas outras") deixam suas marcas na estrutura do canto, acima dividido segundo as unidades consagradas por Hymes (1992) em seu estudo das narrativas chinook. São elas as linhas (cujas palavras estão acima indicadas por letras e numerais minúsculos), as estrofes (indicadas em letras maiúsculas e numerais) e as cenas (em algarismos romanos). A 
primeira cena ${ }^{11}$ (compreendendo as estrofes A1, A2, B1, B2, B3) é aquela em que se visualiza a condição ambivalente do huni, como nos diz a própria expressão "huni karu" (linha 4), ao justapor "lenha (karu) do cipó/homem" a "lenha do homem". Sobrepondo o preparo da bebida alucinógena "ao 'preparo' dos próprios homens, [convertidos em] lenha moída, sovada, e que acaba revelando o núcleo ou gomo onde guarda sua força" (Guimarães 2002:218), a cena inicial do canto mostra o huni deslocado pela nixi pae. Assim tomado pela experiência visionária - pelos passeios do aspecto excorporado de sua pessoa, de sua "alma do olho", o bedu yuxin (Kensinger 1995; Lagrou 1998) - o huni é levado a posições outras: os desenhos ou padrões (kene) que iniciam a experiência do nixi pae se convertem aos poucos em Yube, dona de todos os padrões e também xamã primordial, que em seguida devorará a pessoa.

Entramos então na cena II (estrofes C1, C2, D1, D2, E1, E2, F1, F2), na qual o canto justapõe a visualização de Yube à dos yuxin (os "espíritos" ou as "pessoas" do nixi pae) caracterizados pela cor branca (hushu). São eles a própria yube hushu, o txere hushu (o pássaro curica branca, que é a forma adquirida pelo bedu yuxin ao se desgarrar da pessoa em estados limiares) e yawa hushu (a queixada branca). O que mostra, portanto, este huni muka? A combinação de imagens, o efeito estereoscópico da sobreposição de cenas, nota Guimarães (2002:222), compõem "uma imagem do próprio espírito do olho em sua viagem pelos caminhos da miração". Imagem, porém, que corresponde à experiência imediata do cantador/locutor, isto é, de seu bedu yuxin, e não à experiência mediatizada de ouvintes submetidos a transmissões narrativas como a das akinhá xinguanas: as queixadas-itseke da narrativa Jamugikumalu, presentes na virtualidade memorial do mito, não são as mesmas que as queixadas-yuxin deste canto Kaxinawá, presentes enquanto tais para a alma do olho.

Observemos que a divisão em estrofes e cenas acima sugerida, se segue o modelo de Hymes apenas a título ilustrativo, não deve deixar de ser acompanhada de uma ressalva feita por Tedlock (1983) em seu estudo sobre narrativas Zuñi e Quiché: o arranjo das unidades do canto no instante da performance visualiza algo mais afim a uma ação dramática (como, aliás, bem notou Franchetto para as akinhá Kuikuro) do que à rígida estruturação das formas. Pois a "poesia" aí presente, acompanhando Tedlock e o poeta Charles Olson 1997 [1950], deve ser compreendida para além da limitação do verso ao discurso métrico, a fim de considerá-lo enquanto instância aberta ou projetiva capaz de comportar toda a carga do drama e das possibilidades da respiração: cantos como eventos, portanto, se vale a aproximação com certa poesia contemporânea ocidental. Eventos ou arenas que, no entanto, 
nada dizem de um sujeito lírico ou da criação artística auto-centrada, mas sim das ações e das experiências de cantadores que têm sua pessoa partida em múltiplos aspectos (tais como o bedu yuxin dos Kaxinawá), e assim submetidas às variações posicionais do visível e do invisível (Viveiros de Castro 1986; 2002b). O que a imagética de cantos como o huni muka nos traz é justamente aquilo que apenas cantadores cindidos em sua pessoa podem ver: o que o mito narra e rememora do invisível, cantos tais como os huni muka, por sua vez, mostram (e agem sobre).

\section{Duplos e trajetos}

O efeito estereoscópico aqui examinado muito diz sobre o rendimento especial que a repetição e a ambivalência visual recebem nas cosmologias xamanísticas. Nosso caso, entretanto, não parece se esgotar nos modos pelos quais o paralelismo tem sido compreendido, seja por sua função mnemotécnica, por suas estratégias de captura da atenção da audiência, ou mesmo por seu papel na categorização do mundo social (Lord 1985; Becquelin-Monod 1986; Sherzer 1983; Urban \& Sherzer 1988; Boyer 1990; Severi 1996). As estéticas xamanísticas, "seqüestrando" as variações e as reiterações para diversas de suas expressões (mitologias, grafismos, artes verbais, coreografias, entre tantas outras), as fazem reverberar nos dilemas agentivos, cosmopráticos e relacionais em que se encontram envolvidos os cantadores.

O "xamanismo" aqui considerado, unindo contextos etnográficos e históricos distintos (como no caso de exemplos amazônicos e meso-americanos) refere-se às dinâmicas transformacionais, entendidas como ponto possível de comparação das expressões estéticas relacionadas às cosmologias perspectivas e suas pessoas partidas entre múltiplos aspectos (ver Viveiros de Castro 2002a, 2002b; Gow 2001). Assim sendo, cantos como os marakã Araweté (Viveiros de Castro 2002b), referentes ao complexo do homicídio guerreiro (e apenas aparentemente afastados do xamanismo), são também significativos. No pequeno maraka abaixo citado, vemos o matador (moropi'nã) Araweté cantar/reportar o ponto de vista do espírito de um inimigo Parakanã morto via uma imagética que alude ao estado putrefato do cadáver. Canta aí, dessa forma, um outro: "durante a dança que encerra a reclusão do moropïnã e celebra a morte do inimigo, o espírito deste é dito postar-se imediatamente às costas do matador, que é também o cantador da cerimônia. O inimigo", segue Viveiros de Castro, "é seu 'professor de canto' (marakã memo'o-hã), soprando-lhe ao ouvido as palavras da canção que ele deve proferir" (Viveiros de Castro 2002b:274). Não apenas os versos se engajam em elos paralelos, 
mas as próprias pessoas do matador e de seu inimigo encontram-se justapostas, como assinala o emprego polifônico da primeira pessoa do plural inclusivo no último verso (Viveiros de Castro 1986:589):
(1) Nïpa aramanã
Eis estes besouros-aramanã
(2) Aramanã ika-ika
Os aramanã dependurados,
(3) Nïpa mamãñã
Eis estas mamangabas,
(4) Nane ã woko re
Pendentes de nossos longos cabelos.

Outros são assim não apenas inimigos colados às costas do homicida, mas também os próprios cantadores de exemplares tais como o huni muka Kaxinawá ou o canto Nenets: uma coisa é o corpo/suporte vocal que aqui canta, outra coisa é seu aspecto viajante, que lá está a citar palavras alheias e a mostrar distintas posições. Na tentativa de resgatar certa alma/princípio vital raptada de seu dono doente, o canto de um xamã zinacanteca vincula a reiteração imagética fornecida pela composição em dísticos a referências espaciais ambivalentes, notáveis pelo uso especial dos dêiticos (Haviland 2000:22):

\section{(1) mu xaxh'ayk lok'el/ \\ (2) mu xatenik lok'el \\ (3) yutux amokik un/}

(4) yutuk akoralik un

(5) avilojik li`svokoilik/

(6) avilojik li 'yik'ti'tavalabe/

(7) tanich'nab une kajval

\author{
Não afugente \\ Não expulse \\ Que ela possa ficar em sua cerca \\ em seu curral \\ você viu o sofrimento \\ a miséria de sua cria \\ de seu rebento
}

(Haviland 2000:22) ${ }^{12}$

O xamã aí dirige sua fala a divindades, pedindo que mantenham o doente em seu curral. O curral das divindades, entretanto, está sobreposto no evento do canto ao da vila em que reza o xamã. O canto, diz Haviland, faz "uso de uma gama de verbos de movimento que vinculam as configurações topológicas com as perspectivas e os vetores deiticamente ancorados" (Haviland 2000:21): a estrutura gramatical e a polifonia apontam para a série de eventos paralelos evidenciados pelas rezas, dos quais o xamã é o eixo, e seu canto/evento um índice dos caminhos percorridos. As rezas zinacanteca, cantos/caminhos envolvidos nos trajetos e nas tarefas sociocósmicas, em muito ecoam os trajetos do cantador Nenets, ou mesmo os bai dos cantos Kaxinawá (e de tantos outros grupos falantes de Pano, aliás). Mostram-se abaixo os transportes e as companhias do cantador (Haviland 2000:20): 
(1) $\mathrm{x}$ 'elan ti kunen $k^{\prime}$ ope

(2) ti kunen $t i$ `e

(3) ti bu chixanave

(4) ti bu chibeine

(5) jchi `uk jchamele

(6) jchi `uk i jlajele

(7) ja `no la yech sta ta yu lave `eb

(8) ta yu lavuch'eb
Assim em minha pequena palavra assim em minha pequena fala

Onde ando

onde viajo

Com a pessoa doente com a pessoa ferida

Apenas assim ela encontrou seu lugar de comer

seu lugar de beber

(Haviland 2000:20) ${ }^{13}$

O rendimento da idéia de caminho para o xamanismo não é desconhecido pela etnografia americanista: os estudos de Gallois (1996) sobre os Wayãpi da Amazônia oriental e de Townsley (1993) sobre os Yaminawa do Peru são exemplares. Na mesma direção, o termo kuna ikar revela seu amplo rendimento conceitual: ikar significa, simultaneamente, um caminho propriamente dito (como os que se encontram na selva, nas plantações e em todo o cosmos, ligando suas gentes diversas), mas também um hábito, um costume ou experiência pessoal e, por fim, o próprio canto entoado ${ }^{14}$ na performance ritual (Sherzer 1983:60-61). De longa duração, os cantos ikar são marcados por um gradiente de formalização que acompanha a passagem da língua ordinária às falas rituais (como no caso da "língua dos antigos" Kaxinawá), de que o paralelismo é um índice significativo. Os diversos níveis de paralelismo, além de servirem como critério para marcação de linhas, prestam-se também ao alongamento da performance ritual, a ela conferindo certa regularidade encantatória, de papel essencial para a eficácia da estereoscopia xamanística, e muito comum a cantos relacionados às atividades de cura.

Executados pelos especialistas rituais nele com a ajuda dos bonecos de madeira suar nuchukana (espíritos auxiliares dos nele), os ikar, assim como as rezas Zinacanteca, são eventos de resgate das "almas-princípios vitais" perdidas ou seqüestradas pelas diversas gentes que habitam os também diversos domínios (kalu) do cosmos Kuna. Tais cantos estão associados a vários outros gêneros verbais, dentre os quais os encantamentos sekretto, que combinam palavras de várias línguas "sem conteúdo referencial, evocando, entretanto, uma imagem mística através de suas rimas e ritmos" (Sherzer 1983:117), cuja função é informar o espírito em questão de que o nele conhece sua origem e está assim apto a controlá-lo. Esteticamente apreciados pelos espíritos - os verdadeiros destinatários das palavras e das ações do especialista - os ikar visualizam uma ação que, mais uma vez, 
ocorre simultaneamente "lá" e "aqui": está o nele sentado à beira da rede onde jaz o corpo enfermo // está a viajar com seus espíritos auxiliares pelos kalu e suas gentes diversas ${ }^{15}$. Abaixo seguem citados trechos de um kaeti (ou "agarrador" [grabber], outra variante dos ikar), cujo particular uso do paralelismo nos mostra como a reiteração encantatória empregada nas artes verbais xamanísticas faz o papel de um recurso perspectivo utilizado pelo xamã para cativar o espírito antagônico de seu interlocutor. O texto referese ao momento em que o nele percebe em sua roça a presença do espírito da serpente, Maci oloaktikunappi nele. Enunciado em terceira pessoa, o seguinte ikar é dotado de outra das intrigantes características das artes verbais xamanísticas, aqui apenas anunciada. Descrevendo não apenas a cena visível no canto, mas citando a si mesmo no interior da cena da qual ele é o próprio enunciador, o xamã/cantador descortina uma construção em abismo (Sherzer 1990:264-ss.) ${ }^{16}$ :

(1) ipetiniki purwikan itimienaittikineye

(2) ipetiniki purwikan osamakkenaittikineye

(3) Maci oloaktikunappi nele neka ipekue

(...)

(4) Maci oloaktikunappi nele tar kolesikwisaye

(5) "pule pan kalu saklati nue wisirpatipaye."

(6) Maci oloaktikunappi tar kolesi

(7) apisuati Maci oloaktikunappi uanaeye

(8) "na pe kalu saklati wisikusakupinne.

(9) na pe kalu saklapa totoketanikki.

(10) na pe kalu sakla epiryetanikki

(..)

(12) "apisuati pe purpati wisikusarpa"

(13) kana tar sokekwiciye.

(14) "pe purpati palamisaye."
Enquanto ele corta pequenos arbustos

Enquanto ele elimina pequenos arbustos

Maci oloaktikunappi nele está presente

Maci oloaktikunappi nele chama.

"Como você conhece o lar de minha origem?"

Maci oloaktikunappi está chamando.

O especialista aconselha Maci oloaktikunappi.

"É mesmo, já conheço o lar de sua origem."

É mesmo, eu vim brincar no lar de sua origem

É mesmo, eu vim cercar o lar de sua origem."

"O especialista conhece bem sua purpa O especialista está dizendo.

"Ele capturou a sua purpa" 
(15) kan apisu tar sokekwici.

(16) ipeakselewalapillipaliye.

(17) katili mokimakkenaiye.

(18) kali piknimakkenaikusaye.

(19) Maci oloaktikunappiti tar kolekuiniye.

(20)“ani kan apisuati ani purpati wisikusarpa", sokekuiniye.]

(...)

(23) "ani kana apisuati iki ani satotipa ani kunnuktotipaye."]

(...)

(26) “kati na pe kunnukkewaliye? patto aya nueti na satepinnemalaye.]

(27) kati na pe kunnukkewaliye."

(28) maci oloaktikunappi uanae.
O especialista está dizendo.

Em sua mão.

O cipó está se arrastando

[pendurado]

O cipó está se revirando

[pendurado]

Maci oloaktikunappi chama.

"Meu especialista, você conhece bem minha purpa, ele diz.]

(...)

“Meu especialista, seja lá o que você for fazer comigo você me mataria?"]

"Como eu poderia te matar? Nós acabamos de nos tornar bons amigos.]

Como eu poderia te matar?"

Ele aconselha Maci oloaktikunappi.

$(\text { Sherzer 1990:264-ss.) })^{17}$

A construção em abismo aponta para o dilema da pessoa partida entre seus aspectos: cindido entre a posição imediata da performance e a posição outra em que está Maci oloaktikunappi nele, o especialista Kuna - mas também o matador Araweté ou o cantador Kaxinawá - é pessoa paralela a si mesma. Alongando sua performance pela reiteração paralelística (muito além do que podemos citar aqui), o xamã visa "cercar" seu oponente, fazendo com que aos poucos seja capturada a purpa (alma, princípio vital...) de Maci Oloaktikunnapi nele, e não a sua própria, em uma indesejada inversão de posições. Às voltas com questões similares parece estar o especialista ahituma arotu, o "mestre das dores" dos Warao (Briggs 1994), que se dedica a curar males causados por animais, como arraias, serpentes venenosas, aranhas, escorpiões e vermes. Tais animais possuem duplos: uma mordida ou ferroada leva à inoculação de uma entidade invisível no interior do corpo do doente, chamada de anahe ("o veneno do animal"), anorio ("sua dor"), ahaka ("seu vento") ou aimahana ("sua sombra"). Todos estes termos, nota Briggs, partilham do prefixo genitivo $a-$, indicando que "a dor sentida pelo paciente não é simplesmente propriedade de seu estado corporal, mas um signo sinedóquico da presença invisível do ser 
estranho" (Briggs 1994:142). Enquanto realiza a performance, aqui também permanece o xamã distante do corpo do paciente, e canta o seguinte ahitemoi, cujos fragmentos se referem a uma dentre as quatro partes de mesma estrutura e conteúdo semântico que o compõem (de modo similar aos blocos de paralelismo das akinhá Kuikuro), intercaladas no alongamento reiterativo da performance. A divisão em linhas segue o padrão musical (Briggs 1994:143-ss.):

1 a Bawará sibarí

b bawará sibarí

c bawará sibarí

taisi anahe sebenál

d taisi anahe sebená

e taisi anahe sebená

(...)

4 a Taisi anahemokó, anahe taisi

b taisi anahemokó, mokóna

c taisi anahemokó, mokóna

d taisi anahemokó, mokóna

e taisi anahemokó, mokó, mokóna

(...)

7a Bawará sibarí, taisi hitaná

b taisi hitaná, taisi anahe bomoná

c taisi anahe bomoná

d taisi anahe bomoná

e anahé bomó, bomó, bomoná

(...)

15a Otonomarí hoaba, hoaba buru
Arraia, a que se move no rio com a maré alta

Arraia, a que se move no rio com a maré alta

Arraia, a que se move no rio com a maré alta seu veneno abunda]

seu veneno abunda

seu veneno abunda

Esta aqui, seu pequeno veneno (cria), o veneno desta aqui.

Esta aqui, seus pequenos venenos, seus pequenos

Esta aqui, seus pequenos venenos, seus pequenos

Esta aqui, seus pequenos venenos, seus pequenos

Esta aqui, seus pequenos venenos, seus pequenos

Arraia, a que se move no rio com a maré alta, a espinha sentada desta aqui a espinha sentada desta aqui (daí surge) este veneno delgado este veneno delgado este veneno delgado este veneno delgado

Espírito curador, encha a perna, a perna deste homem 
DE DUPLOS E ESTEREOSCÓPIOS: PARALELISMO E PERSONIFICAÇÃO NOS CANTOS XAMANÍSTICOS AMERÍNDIOS

b hoaba burú sakaná

c sakana hoaba burú

d hoaba buru tatuka, hiomu kobe

horo tatukará]

(...)

69a Hinorio namukarae

b hinorio namukarae

c hinorio namukarae encha da perna ao pé

encha do pé à perna

encha sua perna bem aqui, até a pele da sola de seu pé,

não é aí (que ele foi ferido)?]

Seu veneno, eu o encerrarei.

Seu veneno, eu o encerrarei.

Seu veneno, eu o encerrarei.

(Briggs 1994:143-ss.) ${ }^{18}$

Tal como no ikar Kuna, o canto parece dispor a reiteração paralelística para capturar o ponto de vista do espírito agressor aos poucos familiarizado pelo especialista, que expressa seu conhecimento sobre a origem do duplo da arraia. Não é à toa que o nele passa a empregar (nas linhas 17 e 18) uma metáfora coloquial para serpente (cipó, kali), ao invés do nome do espírito (Maci Oloaktikunnapi nele), assim indicando ter apaziguado sua ameaça (Sherzer 1990). O xamã Warao, por sua vez, utiliza para "arraia" não hue, o nome ordinário de tal animal, mas bawará sibarí, cuja semântica especial denota "a água que flui através de uma seção estreita do rio" (Briggs 1994:148). Mais uma vez mostra estar o especialista informado sobre o modus vivendi de seu oponente, no caso, a arraia causadora do mal, isto é, a arraia visível sobreposta a seu aspecto invisível que lacera o pé do paciente. Para Briggs, "o canto cria, nos termos de Peirce, um ícone diagramático cuja série de ícones individuais se arranjam de modo a estabelecer modelos paralelos dos dois fenômenos" (Briggs 1994:148).

Mais ainda: as distintas relações estabelecidas com o limite corporal pelo xamã Warao e por seu doente são análogas à diferença entre a audiência imediata e os destinatários invisíveis da elocução xamanística, indicando a defasagem das referências sobrepostas pelos cantos. "Enquanto o paciente apenas enxerga a picada e a descoloração superficial, sentindo a dor," escreve Briggs, "o ahituma arotu vê o movimento contínuo da arraia dentro do pé, a contínua laceração produzida por seu ferrão, e o movimento das arraias-bebê no corpo invisível da primeira arraia na panturrilha" (Briggs 1994:149-150). Sobrepondo as posições paralelas em que se situa o cantador, o canto visualiza o caminho do duplo invisível da arraia, que percorre a carne do doente antes de voltar a seu dono, a arraia visível: o termo warao para tal trajeto é anaru que, diga-se de passagem, designa também a estrutura linear do canto ahitemoi (Briggs 1994:154). 


\section{Sujeitos e fantasmas}

Como compreender a re-configuração posicional engendrada pela reiteração paralelística? Vendo a cobra como gente - "Como eu poderia te matar? Nós acabamos de nos tornar bons amigos", dizia o nele a Maci Oloaktikunnapi - o ikar kuna, entre tantos cantos, desencadeia o efeito perspectivo através do "terceiro termo" sobressaído da justaposição. Terceiro termo ou, em outras palavras, a cena geral em que vemos cantadores sobrepostos a seus outros, tais como o inimigo parakanã, o espírito da serpente, os yuxin ou os duplosbebês da arraia. Cantos como o ahitemoi warao, o huni muka kaxinawá e o ikar kuna permitem observar no prolongamento paralelístico não apenas a repetição extensiva dos versos tendo em vista algum efeito estilístico ou mnemotécnico, mas também o aumento do gradiente intensivo, capaz de fazer saltar aos olhos a relação personificante.

Não se trata evidentemente de negar a importância da extensão no paralelismo xamanístico, mas apenas de apontar para o importante papel da intensidade na configuração perceptiva desencadeada pela montagem de cenas. Ecoando as considerações de Deleuze (1988 [1968]), em Diferença e Repetição, Fontanille e Zilberberg assim colocam a questão (1998:95-96, grifo meu):

A visada [visée] consiste em suma na intensidade da tensão que ela instaura entre seus dois extremos, o sujeito e o objeto, ao passo que a preensão [saisie] procede pela delimitação de um extenso, cercando o domínio para aí circunscrever o objeto. Nesta perspectiva, 'arrestar' significa fazer coincidir a extensão de um domínio fechado com o campo no qual se exerce a intensidade da percepção: em um campo assim circunscrito, a intensidade e a extensidade perceptivas evoluem de maneira inversamente proporcional: quanto mais significativo for o número de objetos apreendidos, mais se admite que a percepção é intensa. Em contrapartida, 'visar' é selecionar em um extenso aberto a zona na qual se exercerá a percepção mais intensa; implica em renunciar ao extenso e ao número de objetos em detrimento da saliência perceptiva de alguns ou de apenas um.

O efeito intensivo da estereoscopia não se reduz portanto a um efeito de discurso: não estamos diante de manipulações do logos por alguma epidêixis performativa, tão cara a sofistas e oradores (Cassin 1995) ${ }^{19}$. Aqui, a intensidade parece salientar um locutor privilegiado a partir do pano de fundo das subjetividades virtualmente replicadas (Viveiros de Castro 2002b): é necessário que, em um dado momento da performance, salte à vista um sujeito destacado da extensão, a ser controlado ou familiarizado pelo agente 
do canto (tal como o nele do canto Kuna). Os Candoshi da Amazônia peruana, escreve Surrallés, não se interessam por saber "se os seres com os quais não se comunicam possuem ou não uma forma de vani" ("alma", "princípio vital", ou algo assim). O que importa aos Candoshi é a perspectiva de realidade dos seres com os quais se comunicam "e, conseqüentemente, saber se há ou não como estabelecer relações interativas com tais entidades, ou seja, se a intensidade que elas manifestam as fazem dotadas de uma presença significativa" (Surrallés 2003:47). Aspectos como o vani dos Candoshi não se fixam ao interior, mesmo que vinculados a uma pessoa determinada: "duplo, sombra, imagem, essas conotações implicariam que a 'alma' não é tanto o que está 'dentro' quanto o que se projeta 'fora'", diz Coelho de Souza sobre os karõ/karon/garon dos povos Jê (2002:540). Não devemos dessa maneira tratar tais "aspectos", "duplos" ou "almas" "como uma questão de doutrina, mas como algo aberto à inspeção empírica", assim denotando "não uma substância, mas um modo de ação", completa a autora (Coelho de Souza 2002:536)

Cativando o ponto de vista de duplos e espíritos oponentes, a reiteração prolongada, se algo tem de encantatória, não será pelos efeitos de alguma projeção animista sobre o mundo exterior, de alguma antropomorfização acaso produzida pela "imaginação literária Kuna", como quer Sherzer (1990:242). O uso propriamente agentivo das repetições parece ser algo mais afim à tensão entre alteridade e familiarização a que tem se dedicado certa etnologia americanista recente (Fausto 2002; Viveiros de Castro 2002b) do que a questões de input e output. É porque o cantador se espelha em cobras e arraias; é porque aspectos de pessoas replicadas se desgarram em posições diversas; é porque entidades várias se lançam a um ponto de vista que elas devem ser seduzidas, tornadas próximas ou reféns de mim, a fim de que não se dê o inverso. A diferença intensiva desencadeada pelo prolongamento das repetições é, dessa maneira, um modo de subjetivação:

A relação é criada precisamente pela supressão de um de seus termos, que é introjetado pelo outro; a dependência recíproca que liga e constitui os sujeitos da troca atinge aqui seu ponto de fusão - a fusão dos pontos de vista - onde a distância extensiva e extrínseca entre as partes converte-se em diferença intensiva, imanente a uma singularidade dividida. A relação de predação constitui-se em modo de subjetivação (Viveiros de Castro 2002b:293).

As considerações de Viveiros de Castro, aí referentes ao canibalismo Tupi, parecem também adequadas às dinâmicas personificantes de que tratamos: estas, enquanto modos de subjetivacão, também convertem a 
"distância extensiva e extrínseca entre as partes em diferença intensiva". Tal é o caso do emprego agentivo do paralelismo, cuja dinâmica mútua de cativação (e eficácia) só ocorre entre dois sujeitos distribuídos em suas respectivas posições, e não entre um enunciador e seus personagens imaginativos. O efeito desencadeado pela progressão reiterativa permite que se selecione, a partir do pano de fundo personificado, o sujeito/interlocutor a ser familiarizado/predado/agarrado/controlado, garantindo a ação (terapêutica, cosmoprática) xamanística sobre o ponto de vista concorrente. Mas é preciso que a pessoa seja uma singularidade dividida (ou partida ${ }^{20}$ para que a relação seja intensiva, isto é, para que o 'outro' surja no campo de visão desencadeado pelo canto não como uma 'personagem', mas como um sujeito, fazendo com que tenda ao abismo o evento e a estrutura enunciativa; fazendo com que o caráter paralelo da camada verbal (a estruturação paralelística) seja uma expressão da ubiqüidade ou multiposicionalidade dos eventos cantados. Veículos de alteração e transporte tal como bancos ou indumentárias (Viveiros de Castro 2002b), certos cantos xamanísticos lançam mão da reiteração para expressar ou cumprir as demandas de uma eficácia perspectiva imposta pela sobreposição de referências.

"Nossos olhos seguem um caminho acidentado e irregular até o seu fundo: trata-se de um conjunto de zonas locais de tridimensionalidade, zonas imbuídas de uma claridade alucinatória, mas que, tomadas juntas, nunca se unem em um campo homogêneo", escrevia Crary (1992:126) sobre os estereoscópios do século XIX. A estereoscopia de que falamos não é, entretanto, como a moderna: no xamanismo ameríndio, não se trata de produzir mecanicamente a ilusão desejada pela fantasmagoria dos entretenimentos solipsistas, mas sim de fazer com que a disparidade destaque não objetos ilusórios de uma extensão, mas os sujeitos suspensos na virtualidade personificada.

Dizendo ser a estética melanésia sobre a eficácia, sobre a capacidade de cumprir tarefas, e não imediatamente sobre beleza, Strathern (1988:94) em muito ilumina nosso ponto. Ressoando as considerações de Gell sobre os etua polinésios (1998), a autora notava ser o "simbolismo melanésio" não uma representação, mas um conhecimento ou apreensão de "capacidade e poder animado das coisas" (Strathern 1988:177). O espírito da serpente não é fruto da imaginação literária kuna, como tampouco Yube ou o inimigo que canta pela boca do homicida Araweté; a proliferação de pessoas dos cosmos ameríndios não se compreende por alguma criação autoral, enraizada em nossos pressupostos modernos ${ }^{21}$.

Características como a sinestesia, o paralelismo e seu efeito estereoscópico apontam para o caráter intertradutivo e transformacional das estéticas xamanísticas, irrestritas que são aos limites de "domínios" (cantos, dese- 
nhos, coreografias estarão assim de fato apartados?) ou a meros empregos do estilo ${ }^{22}$. Os fenômenos de sobreposição e repetição muito nos dizem de personificações e replicações, isto é, de pessoas paralelas a si mesmas entre seus duplos e corpos, de imagens e padrões duplicados que são eles próprios duplos, de cantos que são modos de ação sobre outros duplos partidos de seus corpos.

Recebido em $01^{\circ}$. de outubro de 2004

Aprovado em 03 de outubro de 2005

Pedro de Niemeyer Cesarino é doutorando no Programa de Pós-Graduação em Antropologia Social, Museu Nacional - UFRJ. E-mail: < pedroncesarino@ uol.com.br>

\section{Notas}

* O presente artigo é adaptado de minha dissertação de mestrado (Cesarino 2003). Uma versão sua foi apresentada na V Reunião de Antropologia do Mercosul (2002), no grupo de trabalho "Arte e ritual em sociedades indígenas da América do Sul". Agradeço a Bruna Franchetto, Daniel Bueno Guimarães, Eduardo Viveiros de Castro e Elsje Lagrou pelas observações feitas a versões preliminares deste texto. Os exemplos de cantos e narrativas que seguem, quando referentes a fontes do inglês e do francês, foram traduzidos para o português por mim e por Luiza Leite. O leitor interessado deve consultar os originais (nas notas de rodapé) para maiores detalhes sobre os exemplos citados, já que são traduções de traduções, realizadas apenas para esta publicação. Todas as traduções de citações que constem em língua estrangeira na bibliografia são minhas.

${ }^{1} \mathrm{O}$ que consideramos aqui por "cantos xamanísticos" são apenas ficções heurísticas (certamente reais, pois senão não as comentaríamos) que se prestam à investigação de estéticas personificantes atreladas ao xamanismo ameríndio. A expressão "canto xamanístico" refere-se portanto a um vasto campo de expressões verbais cantadas ou entoadas, cuja estilização e padronização (sonoras, gramaticais, semânticas, rítmicas etc.) vêm a destacá-las do fluxo da linguagem cotidiana (ver, por exemplo, Taylor (1983) para os anent Jívaro) para se engajar nas diversas situações de empregos rituais vinculados às cosmopraxis xamanísticas, associadas ou não à figura de um especialista ritual, o dito 'xamã'. Vale notar que os exemplares (e suas análises) apresentados encontram-se divorciados de seus contextos sonoros, rítmicos e musicais, o que evidentemente representa uma perda. 
${ }^{2}$ Sem deixar de esquecer que, ademais, a noção de texto não se reduz apenas a seu aspecto material, como sugerem certos estudiosos da semiótica (ver Fontanille 1998:79-80).

${ }^{3}$ Os versos 15 b e 15 c do canto Warao citado abaixo são um exemplo.

${ }^{4}$ Ver Becquelin-Monod (1986).

${ }^{5}$ Then we found/ the mossy ridge, we found/ at the mossy ridge's foot/ was a lawny hill/ the lawny hill was bored through/ bored through by seven lizards/ "Mother lizard, grandmother/ give a child/ give to my friend!"/ The lizard child, my friend,/ bored through my side./ We found the ice ridge,/ on the side of the ice ridge/ was a blood river,/ the blood river got going,/ the current got going,/ in the blood river's current/ to be cut/ plaits of hair are floating./ I cut the blood river/ bare-handed I cut it,/ the blood river stopped/ the current stopped,/ we crossed the blood river.

${ }^{6} \mathrm{O}$ ponto preciso de distinção entre a autoridade do narrador e de cantadores envolvidos em dinâmicas xamanísticas pode ser verificado pelas diferentes utilizações das modalidades epistêmicas, ou evidenciais (Palmer 1986) que comportam cada registro. Cantos xamanísticos tendem a jogar com evidenciais de experiência imediata e mediada (hearsays), de modo a mostrar que o xamã/cantador está ele mesmo diante da cena reportada por suas palavras; narrativas (míticas, históricas) ancoram-se em contrapartida nos hearsays, fazendo do narrador um porta-voz dos feitos dos outros (ver por exemplo Oakdale [1996]; Basso [1995]; Franchetto [2002b]). Mas, veja bem, o uso dos hearsays é essencialmente distinto em cada caso: nas narrativas, vem a respaldar a autoridade do falante diante do saber imemorial, do qual este é portavoz; nos cantos xamanísticos, vem a ser utilizado pelo cantador para citar pessoas e entidades presentes nos eventos-canto, entre as quais, muitas vezes, ele mesmo (o cantador), ou seu próprio duplo ("alma", "princípio vital"), entre tantos. Tal uso especial dos hearsays em cantos xamanísticos é freqüentemente o responsável por enunciações em abismo. Aprofundo tais questões em outro trabalho (Cesarino 2003), na esteira do que escreveu Viveiros de Castro sobre os cantos Araweté (1986).

7 “...Mère, crois-moi, ce sont des êtres comme ça que nous attendons, ce sont les peres/ quand même comme ça ils voulaient me nourrir/ ils voulaient me nourrir/ les peres/ lá-bas c'est vrai, crois-moi, les pères sont en train de se transformer, maintenant/ leurs dents qui sortaient/ leurs poils sur eux/".

${ }^{8}$ Meus dados preliminares de pesquisa entre os Marubo (falantes de língua Pano do Vale do Javari) indicam isso: muito freqüentemente os cantos xamanísticos iniki se utilizam não apenas das mesmas fórmulas presentes nas narrativas (yoã vaná) e nos cantos míticos (saiti), mas também dos mesmos conteúdos: um episódio mítico pode ser reatualizado na circunstância em que um canto iniki é performado por um espírito yovë (cantando através do xamã romëya), neste momento utilizado, por exemplo, como ironia ou metáfora dirigida aos ouvintes. Algo similar encontramos nos koshoiti Yaminawa traduzidos por Townsley (1993): os cantos re-atualizam o mito de Lua para os fins agentivos da cura. 
${ }^{9}$ Também os Shipibo dizem que seus padrões gráficos possuem uma "ondulação rítmica e ornamentação fragrante e luminosa, similar ao rápido folhear de um livro com muitos desenhos" (Gebhart-Sayer 1986:196). Após ingerir ayahuasca, o xamã Shipibo vê os desenhos projetados por seus espíritos auxiliares: os cantos por ele reportados "serpenteiam no ar" como um todo visualizado a partir das imagens isoladas, traçadas pelos espíritos.

${ }^{10}$ A esquematização de tal estrutura paralelística foi elaborada em conjunto com Daniel Guimarães. O canto que aqui citamos foi traduzido por Guimarães e falantes Kaxinawá bilíngües; realizada a partir de paráfrases e aproximações dos sentidos da língua especial, a tradução disponível é uma experiência (conjunta) de recriação. Vale notar que o esquema do paralelismo aqui mencionado não dá conta do paralelismo interno (entre os constituintes das sentenças).

${ }^{11}$ As cenas do canto em questão não parecem (até onde vai o meu olhar) variar de acordo com demarcadores lexicais específicos - um dos critérios mencionados por Hymes para as narrativas chinook. No entanto, a passagem de um bloco de estrofes a outro se justifica, não apenas pela introdução de um novo conjunto de palavras inexistente no bloco anterior, como pela própria mudança da "estrutura de ação" (outro critério de Hymes [1992:171]) visualizada pelo canto: da justaposição do huni ao huni-cipó à justaposição do huni a Yube e aos yuxin.

${ }^{12}$ Do not drive out/ do not chase out/ May she stay inside your fence/ inside your corral/ you have seen the suffering/ The misery of your child/ of your offspring

${ }^{13}$ Thus in my little word / thus in my little speech/ Where I walk/ where I travel / With the sick person/ with the hurt person/ Only thus has she found your eating place/ your drinking place

${ }^{14}$ Os ikar podem ser namakke (entoados) ou sumakke (falados): no contexto primário de cura, são falados; nos contextos secundários - em festivais, como os ritos de puberdade femininos, ou ao serem ensinados ou executados por mero prazer - costumam ser entoados, embora não haja consenso entre os Kuna sobre tal divisão, conforme nos diz Sherzer (1990:118-119).

${ }^{15}$ Eventos em paralelo (em geral decorrentes da cisão da pessoa entre seu "invólucro corporal" e suas "almas/duplos/princípios vitais") são comuns em diversos regimes sociocósmicos ameríndios, como se vê na caça às queixadas e na cauinagem com os mortos entre os Juruna (Lima 1995; 1996), ou na vida paralela dos Ávila Runa e dos mestres dos animais habitantes do vulcão Sumaco (Kohn 2002), entre tantos outros casos.

${ }^{16}$ Uma análise mais detida de tal ponto está em Cesarino (2003). Ver Viveiros de Castro (1986) para os Araweté, Taylor para os Jívaro (1993), Sherzer (1990) para os Kuna e Bringhurst (1999) para os Haida.

${ }^{17}$ While he is cutting small bushes./ While he is clearing small bushes./ Maci oloaktikunappi nele is present./ Maci oloaktikunappi nele calls./ "How do you know 
the abode of my origin?"/ Maci oloaktikunappi is calling./ The specialist counsels Maci oloaktikunappi./ "Indeed [I] know already the abode of your origin./ Indeed [I] have come to play in the abode of your origin./ Indeed [I] have come to encircle the abode of your origin/ "The specialist knows well your purpa" / The specialist is saying./ "He captured your purpa"/ The specialist is saying./ On his hand./ The vine is dragging [in hanging position]./ The vine is turning over [in hanging position]./ Maci oloaktikunappi calls./ "My specialist [you] know well my purpa,", he says.]/ "My specialist whatever will [you] do to me/ would [you] kill me?"] / "How indeed could [I] kill you? we have just/ indeed already become good friends.]/ How indeed could [I] kill you?"/ He counsels Maci oloaktikunappi.

${ }^{18}$ Stingray, the one who moves in the river with the incoming tide/ Stingray, the one who moves in the river with the incoming tide/ Stingray, the one who moves in the river with the incoming tide, its poison abounds]/ its poison abounds its poison abounds/ This one, its little poison (offspring), the poison of this one./ This one, its little poisons, its little ones/ This one, its little poisons, its little ones/ This one, its little poisons, its little ones/ This one, its little poisons, its little ones / Stingray, the one who moves in the river with the incoming tide, this one's sitting spine]/ this one sitting spine (from there emerges) this one elongated poison]/ this one elongated poison/ this one elongated poison/ this one elongated poison/ Healing spirit, fill the leg, the leg of this man/ fill it from the leg to the foot/ fill it form the foot to the leg/ fill its leg right there, down to the skin of the sole of your foot,/ isn't there (that he was wounded)?]/ Your poison, I shall encapsulate it./ Your poison, I shall encapsulate it./ Your poison, I shall encapsulate it.

${ }_{19}$ Do ponto de vista da praxis enunciativa, parece entretanto que, dentre os quatro esquemas propostos por Fontanille (1998:107); Fontanille \& Zilberberg (1998:133), aquele que mais se aproxima do nosso caso é o esquema da amplificação, no qual "a elevação de informação e de desempenho cognitivo não provoca uma diminuição da intensidade"; pelo contrário, indica Fontanille, o sensível (intensivo) e o inteligível (extensivo) crescem juntos, como em uma construção sinfônica, nas figuras retóricas de amplificação ou na própria ênfase. É aí que nossos problemas com as generalizações semióticas aparecem: de modo similar ao desconforto de Jullien que comentávamos antes, não cabe aqui fazer com que o discurso xamanístico seja um exemplo particular das esquematizações de Fontanille, já que as sacrossantas dualidades (sensível, intelegível; sujeito, objeto; emoção, cognição etc.) sobre as quais repousam o programa de tal semiótica, bem como seu impulso taxonômico, não parecem traduzir bem a replicação personificante do xamanismo. Complexificando o jogo entre os dois extremos, as considerações de Deleuze nos esclarecem mais: “É a intensidade, é a diferença na intensidade que constitui o limite próprio da sensibilidade. Tem ela também o caráter paradoxal desse limite: ela é o insensível, o que não pode ser sentido, porque está sempre recoberta por uma qualidade que a aliena ou que a 'contraria', distribuída num extenso que a reverte e a anula. Mas, de uma outra maneira, ela é o que só pode ser sentido, aquilo que define o exercício transcendente da sensibilidade, na medida em que ela faz sentir e, por isso, desperta a memória e força o pensamento. Apreender a intensidade, independentemente do extenso ou, antes, da qualidade nos quais ela se desenvolve, é o objeto de uma distorção dos 
sentidos" (Deleuze 1988 [1968]:378) No xamanismo, o prolongamento paralelístico parece jogar com tal apreensão: "experiências farmacodinâmicas, ou experiências físicas como as da vertigem aproximam-se disso: elas nos revelam esta diferença em si, esta profundidade em si, esta intensidade em si no momento original em que ela não é mais qualificada nem extensa" (Deleuze 1988 [1968]:378). Não parece ser por acaso, portanto, que o efeito estereoscópico envolva justamente essa antecedência (e dependência) do intensivo sobre o extensivo, como nota ainda Deleuze: "isto foi freqüentemente observado no caso das imagens estereoscópicas; mais geralmente, todo campo de forças remete a uma energia potencial, toda oposição remete a uma 'disparação', e as oposições só são resolvidas no tempo e no extenso na medida em que os disparates tenham, primeiramente, inventado sua ordem de comunicação em profundidade e na medida em que tenham reencontrado esta dimensão em que eles se envolvem, traçando caminhos intensivos que só podem ser reconhecidos no mundo ulterior do extenso qualificado" (Deleuze 1988 [1968]:377). As considerações de Deleuze convergem com o perspectivismo ameríndio, de acordo com a interpretação de Viveiros de Castro (2004:20): "tal como na visão estereoscópica, é necessário que os dois olhos não vejam a mesma coisa dada para que outra coisa (a coisa real no campo de visão) se torne visível [...]".

${ }^{20}$ O termo é uma adaptação do adjetivo inglês "partible", usado por Strathern (1988) para caracterizar a pessoa melanésia. Em sua tese de doutorado, Viveiros de Castro (1986:517) também dizia algo similar sobre a pessoa fendida ou divisível Araweté. A aproximação com a Melanésia, entretanto, deve ser feita com ressalvas: partida certamente, à pessoa ameríndia não parece ser marcante a "fisiologia da troca" (Descola 2001:112) característica dos casos melanésios, mas sim a "absorção da alteridade" (Descola 2001:112) que permeia as dinâmicas de predação do perspectivismo ameríndio. Aqui, a idéia de pessoa se afasta do monadismo ocidental: transindividual, a pessoa ameríndia é virtualmente expandida para além de qualquer limite colocado por um todo atômico, já que envolvida em uma "correlação entre intensidade e extensão", como notou Surrallés (2003:48) para os Candoshi. Os cantos visualizam justamente os dilemas desencadeados por tal expansão. Entretanto, se são as "almas/duplos" que se deslocam, são os "corpos" que criam os pontos de vista, assim desencadeando os equívocos perspectivos com os quais joga o efeito estereoscópico (Viveiros de Castro 2004:20; ver também 2002b). Ainda que não seja possível aprofundar aqui tais complexas questões, cabe lembrar rapidamente que estas supostas "almas" (por vezes glosadas como "duplos" ou "aspectos") mantêm características "corporais" (as "almas" morrem, mantêm relações sexuais, possuem vínculos de parentesco etc.), tornando problemático o uso do par corpo/alma para traduzir a pessoa ameríndia (ver, por exemplo, o que já dizia Carneiro da Cunha [1978] sobre a pessoa Krahô).

${ }^{21}$ Se resistem a equiparações imediatas, tanto com nossa poesia moderna, quanto com agências artísticas ocidentais (como pretendia Overing [1990] a partir do trabalho de Nelson Goodman), é porque não parece ser a criatividade (dos cantadores em sua performance oral) exatamente o problema posto por tais expressões verbais (o que não quer dizer, de modo algum, que não haja aí criação e invenção). Parece-nos que as visualizações dos eventos pelos quais transitam/atuam pessoas 
partidas estão, antes, atreladas ao anseio da eficácia cosmoprática, da diplomacia sociocósmica e dos espelhamentos personificantes em que se vêem envolvidos os cantadores/especialistas. Sua problemática possível gira em torno, portanto, antes dos vetores voltados de fora para dentro do que dos voltados de dentro para fora (ver Viveiros de Castro 1986, 2002b; Coelho de Souza 2002).

${ }^{22}$ Para uma consideração similar envolvendo a estética Kaxinawá, ver Lagrou (2002)

\section{Referências bibliográficas}

BASSO, Ellen. 1995. The last cannibals. Austin: University of Texas Press.

BECQUELIN-MONOD, Aurore. 1986. "Le sang et le corps, ou le blanc et le noir? Contribution à l'étude du parallélisme dans la tradition orale des Maya". Journal de la Societé des Americanistes, LXXII:7-31.

BOYER, Pascal. 1990. Tradition as truth and communication: a cognitive description of traditional discourse. Cambridge: Cambridge University Press.

BRIGGS, Charles. 1994. "The sting of the ray: bodies, agency, and grammar in Warao curing". Journal of American Folklore, 107(423):179-212.

BRINGHURST, Robert. 1999. A story as sharp as a knife: the classical Haida myth tellers and their world. Vancouver: Douglas \& Mcintyre / University of Nebraska Press.

CARNEIRO DA CUNHA, Manuela. 1978. Os mortos e os outros. São Paulo: Hucitec.

CASSIN, Barbara. 1995. L'effet sophistique. Paris: Gallimard.

CESARINO, Pedro. 2003. Palavras torcidas: metáfora e personificação nos cantos xamanísticos ameríndios.
Dissertação de Mestrado, PPGAS/ Museu Nacional/ UFRJ.

COELHO DE SOUZA, Marcela. 2002. O traço e o círculo. Tese de Doutorado, PPGAS/ Museu Nacional/ UFRJ.

CRARY, Jonathan. 1992. Techniques of the observer. Cambridge: MIT Press.

DESCOLA, Philippe. 2001. "The genres of gender: local models and global paradigms in the comparison of Amazonia and Melanesia". In: T. Gregor \& D. Tuzin (orgs.), Gender in Amazonia and Melanesia: an exploration of comparative method. Berkeley: University of California Press. pp. 91-114.

DELEUZE, Gilles. 1988 [1968]. Diferença e repetição. Rio de Janeiro: Graal.

FAUSTO, Carlos. 2002. "Banquete de gente: comensalidade e canibalismo na Amazônia". Mana. Estudos de Antropologia Social, 8(2):7-44.

FINNEGAN, Ruth. 1992. Oral poetry. Bloomington: Indiana University Press.

FONTANILLE, Jacques. 1998. Sémiotique du discours. Limoges: Presses Universitaires de Limoges.

. \& ZILBERBERG, Claude. 1998. Tension et signification. Hayen: Mardaga. 
FOX, James. 1977. "Roman Jakobson and the comparative study of parallelism". In: D. Armstrong \& C. H. Van Schooneveld (orgs.), Roman Jakobson, echoes of his scholarship. Lisse: The Peter de Ridder Press.

(org). 1988. To speak in pairs: essays on the ritual languages of eastern Indonesia. Cambridge: Cambridge University Press.

FRANCHETTO, Bruna. 2002a. "L'autre du même: parallélisme et grammaire dans l'art verbal des récits Kuikuro (caribe du Haut Xingu, Brésil)". Amerindia, 28:213-248.

. 2002b. "Les marques de la parole vraie en kuikuro". In: J. Landaburu e Z. Guentchéva (orgs.), Modalités epistemiques. Paris: Peeters. No prelo.

GALLOIS, Dominique. 1996. "Xamanismo waiãpi: nos caminhos invisíveis, a relação i-paie". In: J. Langdon (org.), Xamanismo no Brasil: novas perspectivas. Florianópolis: Editora da UFSC. pp. 39-74.

GEBHART-SAYER, A. 1986. "Una terapia estética. Los diseños visionarios del ayahuasca entre los Shipibo-Conibo". América Indígena, 46:189-219.

GELL, Alfred. 1998. Art and agency. Oxford: Clarendon Press.

GOW, Peter. 2001. An amazonian myth and its history. Oxford: Oxford University Press.

GUIMARÃES, Daniel. 2002. De que se faz um caminho - tradução e leitura de cantos Kaxinawá. Dissertação de Mestrado, Universidade Federal Fluminense.

HAVILAND, John. 2000. "Dangerous places in zinacantec prayer". Comunicação apresentada no colóquio Les espaces mayas: représentations, utilisations, croyances. Nanterre: Université de Paris X. Publicado em A. Breton, A. Monod-Becquelin e M. H. Ruz (orgs.), Los espácios mayas : representaciones, usos, creencias.
México: Editora de la Universidad Autónoma de México. pp. 383-428.

HYMES, Dell. 1992. In vain I tried to tell you. Philadelphia: University of Pennsylvania Press.

JAKOBSON, Roman. 1963. Essais de linguistique générale. Paris: Les Éditions de Minuit. 1970. "Poesia da gramática e gramática da poesia". In: Lingüística, poética, cinema. São Paulo: Perspectiva.

. 1985. "Il parallelismo grammaticale e il suo aspetto russo". In: Poesia e poetica. Torino: Einaudi.

JULLIEN, François. 1989. "Présentation". Extrême-Orient - Extrême Occident, 11:7-11.

1989b. "Une vision du monde fondée sur l'appariement: enjeux philosophiques, effets textuels (a partir de Wang Fuzhi)". Extrême-Orient - Extrême Occident, 11:45-53.

. 1989c. Procès ou création. Paris: Seuil.

KENSINGER, Kenneth. 1995. How real people ought to live. Illinois: Waveland Press.

KOHN, Eduardo. 2002. Natural engagements and ecological aesthetics among the Ávila Runa of amazonian Ecuador. Ph.D. Dissertation, University of Winscosin-Madison.

LAGROU, Elsje. 1998. Caminhos, duplos e corpos. Tese de Doutorado, Universidade de São Paulo. 2002. "O que nos diz a arte kaxinawá sobre a relação entre identidade e alteridade?". Mana. Estudos de Antropologia Social, 8(1):29-63.

LIMA, Tânia Stolze. 1996. "O dois e seu múltiplo: reflexões sobre o perspectivismo em uma cosmologia tupi". Mana. Estudos de Antropologia Social, 2(2):21-49. . 1995. A parte do cauim: etnografia juruna. Tese de Doutorado, PPGAS/ Museu Nacional/ UFRJ. 
LORD, Albert. 1985. The singer of tales. Nova York: Atheneum.

MIRANDA, Marlui (org). 2005. Ponte entre povos. São Paulo: SESC.

NORDENSKIÖLD, Erland. 1938. An historical and ethnological survey of the cuna indians. Göteborg: Göteborgs Museum.

OAKDALE, Suzanne. 1996. The power of experience: agency and identity in kayabi healing and political process in the Xingu indigenous park. Ph.D. Thesis, Universidade de Chicago.

OLSON, Charles. 1997 [1950]. "Projective verse". In: Collected prose. Berkeley: University of California Press. pp. 239-250.

OVERING, Joanna. 1990. "The shaman as a maker of worlds: Nelson Goodman in the Amazon". Man, 25(4):602-620.

PALMER, Frank Robert. 1986. Mood and modality. Cambridge: Cambridge University Press.

SEVERI, Carlo. 1996. La memoria ritual. Quito: Ediciones Abya-Yala.

2004. Il percorso e la voce. Torino: Einaudi.

SHERZER, Joel. 1983. Kuna ways of speaking. Austin: University of Texas Press.

1990. Verbal art in San Blas. Albuquerque: University of New Mexico Press.

SIMONCSICS, Péter. 1978. "The structure of a Nenets magic chant". In: V. Diószegi' \& M. Hoppál (orgs.), Shamanism in Siberia. Budapeste: Akadémiai Kiadó. pp. 378-402.

STRATHERN, Marilyn. 1988. The gender of the gift. Berkeley: University of California Press.

SURRALLÉS, Alexandre. 2003. Au coeur du sens. Paris: CNRS Éditions.

TAYLOR, Anne-Christine. 1983. "Jivaroan magical songs: Achuar anent of connubial love". Amerindia, VII:87-127.
1993. “Des fantômes stupéfiants - language et croyance dans la pensée achuar". L'Homme, 126128:429-447.

TEDLOCK, Dennis. 1983. The spoken word and the work of interpretation. Philadelphia: University of Pennsylvania Press.

TOURNON, Jacques. 1991. "Medicina y visiones: canto de un curandero Shipibo-Conibo, texto y contexto". Amerindia, 16:179-209.

TOWNSLEY, Graham. 1993. "Song paths: the ways and means of yaminawa shamanic knowledge". L'Homme, 126-128:449-468.

URBAN, Greg \& SHERZER, Joel. 1988. "The linguistic anthropology of native South America". Annual Review of Anthropology, 17:283-307.

VIVEIROS DE CASTRO, Eduardo. 1986. Araweté, os deuses canibais. Rio de Janeiro: Zahar/Anpocs.

.2002a. "O nativo relativo". Mana. Estudos de Antropologia Social, 8(1):113-149. . 2002b. A inconstância da alma selvagem. São Paulo: Cosac \& Naify. . 2004. "Perspectival anthropology and the method of controlled equivocation". Tipití, 2(1):3-22.

ZUMTHOR, Paul. 1983. Introduction à la poésie orale. Paris: Seuil. 
Resumo

Este artigo apresenta um estudo de exemplares das artes verbais xamanísticas, em sua maioria provenientes da América do Sul, a partir de suas estruturações paralelísticas, isto é, dos efeitos de repetição e justaposição de imagens e versos. Pretende-se não apenas realizar uma revisão bibliográfica do assunto, mas também relacionar o fenômeno da repetição verbal em cantos e narrativas a certas considerações atuais da etnologia americanista, tais como as dinâmicas de personificação, agência sociocósmica e predação. O artigo pretende ainda oferecer pistas e contribuições para o estudo das estéticas transformacionais ameríndias a partir de uma análise comparativa sobre traços específicos da oralidade em performance ritual.

Palavras-chave: Xamanismo, Oralidade, Paralelismo, Personificação, Poética

\section{Abstract}

This article is a study of various examples of the shamanic verbal arts, the majority taken from South America. It takes as its starting point their parallelistic constructions - that is, the effects produced by repeating and juxtaposing images and verses. As well as providing a bibliographic survey of the topic, it also explores the relationship between the phenomenon of verbal repetition in chants and narratives, and various contemporary issues in Americanist anthropology, such as the dynamics of personification, sociocosmic agency and predation. The study also proposes a number of new directions in the study of Amerindian transformational aesthetics, based on the comparative analysis of specific traits of orality in ritual performance.

Key words: Shamanism, Orality, Parallelism, Personification, Poetics 